IZA DP No. 4736

Returning to the Question of a Wage Premium for Returning Migrants

Alan Barrett Jean Goggin

February 2010 


\title{
Returning to the Question of a Wage Premium for Returning Migrants
}

\author{
Alan Barrett \\ Economic and Social Research Institute \\ and IZA \\ Jean Goggin \\ Economic and Social Research Institute
}

Discussion Paper No. 4736

February 2010

\author{
IZA \\ P.O. Box 7240 \\ 53072 Bonn \\ Germany \\ Phone: +49-228-3894-0 \\ Fax: +49-228-3894-180 \\ E-mail: iza@iza.org
}

\begin{abstract}
Any opinions expressed here are those of the author(s) and not those of IZA. Research published in this series may include views on policy, but the institute itself takes no institutional policy positions.

The Institute for the Study of Labor (IZA) in Bonn is a local and virtual international research center and a place of communication between science, politics and business. IZA is an independent nonprofit organization supported by Deutsche Post Foundation. The center is associated with the University of Bonn and offers a stimulating research environment through its international network, workshops and conferences, data service, project support, research visits and doctoral program. IZA engages in (i) original and internationally competitive research in all fields of labor economics, (ii) development of policy concepts, and (iii) dissemination of research results and concepts to the interested public.
\end{abstract}

IZA Discussion Papers often represent preliminary work and are circulated to encourage discussion. Citation of such a paper should account for its provisional character. A revised version may be available directly from the author. 
IZA Discussion Paper No. 4736

February 2010

\begin{abstract}

\section{Returning to the Question of a Wage Premium for Returning Migrants}

Using data from a large-scale survey of employees in Ireland, we estimate the extent to which people who have emigrated from Ireland and returned earn more relative to comparable people who have never lived abroad. In so doing, we are testing the hypothesis that migration can be part of a process of human capital formation. We find through OLS estimation that returners earn 7 percent more than comparable stayers. We test for the presence of self-selection bias in this estimate but the tests suggest that the premium is related to returner status. The premium holds for both genders, is higher for people with postgraduate degrees and for people who migrated beyond the EU to the US, Canada, Australia and New Zealand. The results show how emigration can be positive for a source country when viewed in a longer term context.
\end{abstract}

JEL Classification: J61, O15

Keywords: return migration, Ireland, brain drain, brain circulation

Corresponding author:

\author{
Alan Barrett \\ Economic and Social Research Institute \\ Whitaker Square \\ Sir John Rogerson's Quay \\ Dublin 2 \\ Ireland \\ E-mail: Alan.Barrett@esri.ie
}

\footnotetext{
* We would like to acknowledge helpful with Daniel Hamermesh and Séamus McGuinness and participants at an ESRI seminar. We would also like to acknowledge the funding provided by the Irish Research Council for the Humanities and Social Sciences under the Government of Ireland Thematic Research Project Grants Scheme. Finally, we would like to thank Mary Smyth of the Central Statistics Office for facilitating access to the data.
} 
Returning to the Question of a Wage Premium for Returning Migrants

\section{Section 1: Introduction}

The basic model which underpins much of the research on the economics of immigration predicts that migration occurs if the net present value of earnings in the host country exceeds the net present value of earnings in the home country, adjusting for the costs of migration (Sjaastad, 1962). Under certain assumptions, this model suggests that migrations, once undertaken, will tend to be permanent. According to Dustmann and Weis (2007) "much of the theoretical and empirical literature on the economics of migration views migrations as permanent” and it seems reasonable to suggest that the Sjaastad model contributed to that view being taken in subsequent research.

In reality, many moves are not permanent and the extent of return migration has been shown to be significant. For the United States, Jasso and Rosenzweig (1982) have shown that 15.7 million people immigrated between 1908 and 1957 and that about 4.8 million aliens emigrated. Warren and Peck (1980) estimate that around a third of people who immigrated legally re-emigrated in the 1960s. For the UK, Dustmann and Weis (2007) estimate out-migration rates of 40 percent for men and 55 percent for women after five years, using data from the 1990s. Looking at the issue from a source country perspective, the data used in this paper show that in 200615 percent of the Irish native workforce had lived outside of Ireland for a period of at least one year.

Once migration is introduced in models as a temporary rather than a permanent phenomenon, a host of implications arise. For example, the incentives facing migrants as regards the accumulation of both financial and human capital may differ according to whether they see themselves as being temporary or permanent migrants. The impacts of migration on both host and home countries will also differ, depending on whether inflows and outflows are temporary or permanent and also depending on the selective nature of return flows. In the case of developing countries, concerns about "brain drain" are 
lessened if outflows are temporary; indeed, outflows can be seen in positive terms if they are part of a process of "brain circulation" as opposed to "brain drain".

Given the importance of return migration both in quantitative terms and in terms of our understanding of the behaviour of migrants and their impacts, contributions to the body of research looking at the issue are also important. In this paper, we aim to provide such a contribution by using a unique, large-scale dataset from Ireland which identifies both returned migrants and "stayers". The data allow us to compare the earnings of the two groups and so to assess whether returning migrants enjoy a wage premium relative to stayers. Ireland has experienced periods of both significant emigration and return migration, thereby providing a valuable setting in which to study this issue.

The remainder of the paper is structured as follows. In Section 2, we review the literature on return migration, including the limited set of papers which have looked at the issue of possible wage advantages for returned migrants. In Section 3, we describe the data and the methods used in the empirical analysis. Our basic approach is to estimate Mincer-type wage equations using OLS, where we include amongst the explanatory variables a dummy variable equal to one if the individual is a returned migrant and zero otherwise. We are mindful of the possible presence of self-selection effects so we also attempt to assess if such effects are driving any observed wage premium. Given that such selection effects appear to be absent, we rely mostly on OLS estimates. In Section 4, we present both descriptive statistics and the results from the econometric analysis. Section 5 contains a summary and discussion.

\section{Section 2: Literature}

According to Dustmann and Weiss (2007), it is possible to model return migration in three ways. First, it could be that individuals place a higher value on consumption in the home country relative to the host country. In this situation, although lifetime income might be maximised by living in the host country, lifetime utility maximisation could be achieved by spending some time in the host country and then returning home (Djajic and 
Milbourne, 1988). Second, it could be the case that the host country currency has a higher purchasing power in the home country. It is then possible to maximise consumption, and hence utility, by returning to the home country. Third, if human capital acquired in the host country is better rewarded in the home country, then lifetime income could be maximised through temporary migration (Dustmann, 1997a).

A number of papers have considered how the temporary nature of migration will impact upon decision-making by the individual. Dustmann (1997b) looks at the savings behaviour of migrants while Dustmann and Kirchkamp (2002) look at the duration of migration and activities after return. Dustmann (2003) explores how the likelihood of return migration impacts upon human capital investment by parents in their children.

The idea in Dustmann (1997a) that emigration and return migration could be part of process of human capital accumulation led to a numbers of papers which looked at the labour market outcomes for returning migrants relative to compatriots who had not emigrated. Were the Dustman thesis correct, this would tend to be reflected in higher wages for returning migrants. Co et al (2000) used data from Hungary to explore the issue and found a wage premium for women returners but not for men. Barrett and O'Connell (2001) looked at a sample of Irish graduates and found a wage premium for men but not for women. Hazans (2008) considers the case of Latvia and finds a wage premium of 20 per cent for men and 6 per cent for women. In the case of each paper, attempts are made to account for possible selection effects. In de Coulon and Piracha (2005), the selection issue is central and results are presented in terms of how nonmigrants would have done had they chosen to migrate and return (they would have earned more than twice the wages of return migrants).

Section 3: Data and Methods

The data used in this study comes from the October 2006 National Employment Survey (NES). The 2006 NES is a workplace survey, covering both the public and private sectors, which was conducted by the Central Statistics Office (CSO). The information 
contained in the NES was collected from a matched employee-employer survey. The employer sample was drawn using the CSO Central Business Register (CBR). Selected firms were asked to draw a systematic sample of employees from their payroll, following guidelines which the CSO provided to ensure that the samples of employees had desirable statistical properties. Approximately 8,000 enterprises ${ }^{2}$ were contacted of which 4,200 responded resulting in employee information on 51,300 individuals. After the elimination of employees with missing earnings information, part-time students and also the restriction of our sample to those of working age, the final sample for this study was just below 50,000 employees.

October 2006 was the reference period for the survey. The employer questionnaire collected information on the earnings of employees and also hours worked and occupational details ${ }^{3}$. Employers also provided limited information on firm size, amounts of training provided to employees and on skills deficiencies within the firm. The measure for earnings used in the analysis below is the weekly rate of pay for each individual employee as derived from their employer's responses to questions on employees gross monthly pay in the reference period (October 2006) ${ }^{4}$.

Employees were issued with a separate survey within which they were asked to provide information on their age, gender, educational attainment, employment status (part-time or full-time), experience (measured in terms of length of time in paid employment) and also other job-related characteristics (for example, trade union membership, supervisory role, tenure with current employer). In terms of migration, each individual is asked about their nationality so we are able to restrict the sample to Irish nationals only. All individuals are also asked if they have ever lived outside of Ireland for a continuous period of one year or more. If they answer yes, we code that individual as being a returned former emigrant; if they answer no, the individual is coded as "stayer”.

\footnotetext{
${ }^{2}$ Only employers with more than three employees were surveyed and the data were collected at the enterprise level.

${ }^{3}$ The earnings information collected in the 2006 NES represents the gross monthly amount payable by the organisation to its employees. This includes normal wages, salaries and overtime; taxable allowances, regular bonuses and commissions; and holiday or sick pay for the period in question (October 2006). It does not include employer's social insurance payments redundancy payments and back pay.

${ }^{4} \mathrm{~A}$ fuller description of the sampling and survey methods can be found in Central Statistics Office (2007)
} 
With respect to the methodology used to model the impact of migration on earnings, we begin with a standard Mincer type wage model that can be written as follows:

$\log w=\beta_{1}+\beta_{2} E x+\beta_{3} E x^{2}+\beta_{4} S+\beta_{5} X_{1}+\beta_{6} M i g+\varepsilon_{i}$

where Ex is experience, $\mathrm{S}$ is a vector of schooling dummy variables (denoting highest qualification ), $\mathrm{X}$ is a vector of explanatory variables containing both employee and employer characteristics that relate to earnings and Mig is the returner dummy variable discussed above. The coefficient on Mig provides an estimate of the earnings disadvantage of returners relative to natives evaluated at the mean.

If returners and stayers differ in ways that are correlated with earnings, OLS may generate a biased estimate of the earnings gaps. A particular concern is that returned migrants might simply be a more motivated group relative to stayers and hence would have experienced higher earnings whether they had migrated or not. In order to assess is this is indeed an issue, we employ three approaches. First, we run a two-stage Heckman treatment model in which the probability of being a returner is estimated first and then a correction terms is added to the earnings equation to account for possible selection effects. A key element in running this procedure is the identification of a variable which is correlated with the likelihood of being a returned migrant but not with current earnings. The variable we use is the rate of unemployment is the year that the individual left full time education. As will be seen below, our use of this approach turns out to be inconclusive so we employed a second strategy, instrumental variables. Under this approach, we again use the rate of unemployment is the year that the individual left full time education as an instrument to predict whether an individual is a returner and then use the predicted values of being a returner in the wage regression. As an additional check on the issue of selectivity, we use a third strategy, propensity score matching and the Rosenbaum r-bounds test. This is discussed at greater length below.

Section 4: Results 
As mentioned, we restricted our sample to Irish nationals. Following the elimination of observations due to missing values, we were left with a final sample of 42,843, of which 36,627 are stayers and 6,216 are return migrants. In Table 1 we present the mean values of all the variables used in our analysis. These are presented separately for stayers and returners, with indications of statistically significant differences between these two groups. The most interesting difference between stayers and returners is their average earnings: returners are paid almost $€ 180$ more per week. This amounts to a wage premium for returners of approximately 25 per cent and is significant at the 1 per cent level. The two groups differ significantly across a range of variables, with returners likely to be older and more experienced on average, and less likely to be male. Returners are more likely to hold a degree or postgraduate qualification than stayers, and in terms of occupation are more likely to belong to the categories of managers and senior administrators, professionals, and associate professional and technical. Returners are less likely to work in the manufacturing sector or the wholesale and retail sector than stayers are, and are significantly more likely to work in health and social work, business services, and education.

Moving on to our regression analysis, we estimated the wage equation shown above in (1), using the log of weekly earnings as the dependent variable. The results are shown in Table 2. We find a positive and significant wage premium for returned migrants relative to stayers. The coefficient on the returner dummy variable indicates that returned migrants enjoy a 7 per cent wage premium, significant at the 1 per cent level. Looking at the other variables in the regression, age, experience and tenure are all positive and significant as would be expected. Workers living in Dublin earn 16 per cent more than those living elsewhere. The coefficients on the education variables are also as expected. Relative to workers who possess just primary school education, workers with higher levels of education earn a positive and significant wage premium.

As shown in Table 1, the characteristics of stayers and returners differ significantly. If returners and stayers differ in ways that are correlated with earnings, then OLS may 
produce a biased estimate of the returned migrant wage premium. For example, it could be the case that a more motivated or capable individual chooses to migrate (and subsequently return), and so this individual would have been expected to earn a higher wage whether they had migrated or not. To check the robustness of our OLS estimate and to take account of any such selection issues, we employ three alternative strategies: Heckman selection correction, instrumental variables and propensity score matching.

The Heckman selection correction technique allows us to account for selection along unobserved individual characteristics. To do this we require an instrument that is a suitable predictor of being a returned migrant, but is uncorrelated with earnings in 2006. We used the rate of unemployment in Ireland in the year the individual left full time education ${ }^{5}$. The results from the stage one probit confirm that this is a suitable instrument - the coefficient on this variable is positive and significant at 1 per cent. In the second stage of the Heckman procedure a contradictory pair of results emerges. On the one hand we find that the estimated returner wage premium is no longer significant; this would suggest that selection was present. However, the coefficient on Lambda, the selection correction term, is also insignificant suggesting that the selection bias is not quantitatively important.

As the Heckman approach yielded an inconclusive result with regard the presence or otherwise of a self-selection bias, we moved on to assess the selection issue using instrumental variables (IV) methods. In the first stage, the returned migrant dummy variable is regressed on the instrument (again, we use the rate of unemployment in the year of graduation) and on the other control variables from equation (1). The first stage $F$ statistic confirms that our instrument is sufficiently strong. The predicted values of the returned migrant dummy are then used as a new independent variable in the second stage.

\footnotetext{
${ }^{5}$ In order to create this variable, an assumption was needed. As we had information on age and highest level of education, we could work out the year that the individuals left full-time education if we assumed that all education was acquired in a continuous period from primary school. While this assumption will be untrue in some cases, the variable does act as a useful predictor of being a returned migrant.
} 
The results suggest that our OLS finding is robust - the IV estimate of the returned migrant wage premium is positive and significant at the 1 per cent level ${ }^{6}$.

As a final sensitivity check, we re-estimate the wage equation using propensity score matching (PSM) methods. The logic behind this approach is that the stage one probit will identify the over-riding observable factors that distinguish a returned migrant from a nonmigrant. The PSM framework then draws a control group from the population of nonmigrants and matches them, as much as possible, to the treatment group of returned migrants, ensuring a more comprehensive "like-with-like" comparison. We achieve an appropriately balanced dataset for PSM estimation by using a relatively basic probit specification, centred around the standard human capital framework. In Table 3 we report the estimated returner wage premium generated by the Nearest Neighbour and Kernel matching techniques. We find no significant wage premium using the Nearest Neighbour method. However, using the Kernel matching technique we find an 8 per cent wage premium, significant at 1 per cent. We also checked the PSM estimate's sensitivity to unobserved factors by applying post-estimation Rosenbaum bounds. The bounds allow us to assess the extent to which an unobserved variable must influence the selection process in order to render the PSM estimate unreliable. The results are shown in Table 4 and they suggest that our estimated wage premium is likely to be robust to such effects. As Gamma increases as high as 1.6, the p-values indicate that our estimate of the wage premium remains reliable. This implies that even in the event of an unobserved factor increasing the likelihood of an individual being a returned migrant by a factor of 60 per cent, our estimate of the wage premium remains reliable.

Based on the IV analysis and the results from the Kernel matching in particular, it seems that selection is not a major concern. Hence, we now go on to look at the wage premium for returning migrants along a number of dimensions using OLS regressions again. Returning to the results of our first OLS estimation above, returned migrants are found to earn a wage premium of 7 per cent. A number of empirical studies have found that the

\footnotetext{
${ }^{6}$ The coefficient estimate on the returner variable in the IV regression is 0.36 , with a standard error of .09 . As the variable in the IV regression is continuous, being a predicted value, it is not readily comparable to the coefficient estimate from the OLS model where the variable is dichotomous.
} 
wage premium can vary significantly by gender. In the previous empirical study of returned Irish migrants, Barrett and O’Connell (2001) found a wage premium for men but no wage premium for returned female migrants. In the Latvian study, Hazans (2008) reported a wage premium for both men and women, but the wage premium for male returned migrants was 20 per cent, while for females it was just 6 per cent. We reestimated the wage equation separately for men and women and in Table 5 we report the returned migrant wage premium by gender. ${ }^{7}$ As shown, we find no gender differences the wage premium for both male and female returned migrants is estimated at 7 per cent.

In Table 6, we re-estimate the wage equation five times, restricting the sample to a different education category each time. While the study by Barrett and O’Connell (2001) used data from a survey of Irish college graduates, the National Employment Survey data contains information on individuals with varying levels of education. Therefore, it allows us to identify whether the returned migrant wage premium exists at all levels, or merely at the higher levels of educational attainment. If it is the case that emigration and return migration are part of a process of human capital accumulation, then we might expect to observe a wage premium only at the higher levels of education. However, as Table 6 shows, we find a significant wage premium for returned migrants relative to stayers at each education level. Returners who possess a postgraduate qualification earn a 10 per cent wage premium relative to stayers with postgraduate qualifications. This wage premium falls to 5 per cent for workers with secondary or postsecondary qualifications. The premium increases again at primary level education, with returned migrants earning 13 per cent more than stayers. However, when we tested to see if the differences among these coefficients were statistically significant, we found that while the 10 per cent premium at postgraduate level was statistically different from the 5 per cent premium at secondary or postsecondary level, the difference in premium between primary and all other education levels was not significant.

\footnotetext{
${ }^{7}$ Tables 5-9 only report the coefficient estimates on the variable of interest. All standard controls were included in the estimations.
} 
The National Employment Survey asks respondents who previously migrated to indicate the year in which they returned to Ireland. Using this information, we can examine how the earnings of returned migrants are affected by the length of time since their return. We re-estimate the wage equation, restricting the sample to returned migrants and including a continuous variable measuring the number of years since the individual returned to Ireland. As shown in Table 7, we find a negative and significant relationship between an individual's earnings and the length of time since their return, indicating that migrants who have recently returned to Ireland enjoy higher earnings than those who returned a number of years ago.

Barrett and O'Connell (2001) were able to distinguish between returners who migrated for labour reasons, and those who left for non-labour reasons (left with family, or went for adventure reasons). Using this information they found a difference in wage premium across these two groups of returners. They reported an 8 per cent wage premium for labour-related migrants, and no wage premium for those who migrated for non-labour reasons. The NES dataset also allows us to distinguish between returned migrants who worked while they were abroad and those who did not. We re-estimated the wage equation using these two returner dummy variables, rather than just one, with the reference category still being the group of non-migrants. The results are given in Table 8, and show that the wage premium is found for both groups of returners. However, those who worked while abroad earn a 6 per cent wage premium relative to stayers, while those who did not work earn just 3 per cent more than stayers ${ }^{8}$. A simple test indicates that these premia are statistically different.

Finally, in Table 9 we examine the extent to which the returned migrant wage premium depends on the destination of the migrant. We replace the returner dummy with five separate dummies, allowing us to identify migrants returning from the UK; the USA/Canada; the European Union (excluding the UK); Australia/New Zealand and all other countries. Once again the reference category is the group of non-migrants. We find

\footnotetext{
${ }^{8}$ The sample size for this regression was reduced to just under 42,000. This was due to the elimination of a number of observations relating to returned migrants who did not indicate if they worked while abroad.
} 
no significant wage premium for migrants who have returned from the European Union. The wage premium exists for all other migrant destinations, however, the size of the premium varies considerably. Interestingly, migrants who have returned from the USA or Canada earn 11 per cent more than non-migrants, while the premium for those returning from the UK is just 5 per cent. A significance test confirms that these estimated wage premia are statistically different from each other. Migrants who returned from Australia or New Zealand earn 10 per cent more than non-migrants, and again this premium is statistically different from the 5 per cent UK premium.

\section{Section 5: Conclusions}

A growing number of studies have shown how emigration and subsequent return can be seen as part of a process of human capital formation. The observation of higher wages for returned migrants relative to comparable stayers in a number of cases is certainly consistent with this view. In this paper, we have added to the limited number of studies on this question and have again found a positive and significant effect of return migration on wages. The wage premium is about 7 percent in our analysis and appears to hold even when possible self-selection is controlled for.

In addition to estimating the premium on average, we have also shown that it is present for both genders, in contrast to some earlier studies including Barrett and O’Connell (2001). The premium is higher for those with post-graduate degrees relative to those with primary degrees and secondary schooling. It is also higher for people who travelled beyond the UK and the rest of the EU. While the premium for those who lived in the UK and the rest of the EU was 5 percent and 4 percent respectively, it was 11 percent for those who went to live in Canada or the US and 10 percent for those who went to live in Australia or New Zealand. Finally, the premium appears to diminish over time at a rate of 1 percent per year.

The results in this paper add to a growing view of emigration that it can have positive impacts on source countries. Some of the literature in this area has looked at the impact 
of remittances. Other papers have looked at the relationship between skilled outward migration, i.e. a brain drain, and human capital formation across countries. In this context, Beine et al (2008) show how there seems to be a positive relationship and conclude that "the traditionally pessimistic view of the brain drain has no empirical justification at an aggregate level". Our results show another route through which emigration can be positive from the perspective of a source country, once the timeframe of analysis is long enough for emigration and return to occur. In the case of Ireland, this process whereby people leave and then subsequently return with enhanced levels of human capital has been described as one of a number of features that contributed to the Celtic Tiger (FitzGerald, 2000) so its quantitative impact appears to be potentially considerable. It is possible that the "brain circulation" process will begin to work soon in countries such as Poland and other Eastern European countries that experienced large population outflows following EU expansion in 2004. 


\section{References}

Barrett, A. and P.J. O’Connell, (2001), “Is There a Wage Premium for Returning Irish Migrants”, Economic and Social Review Vol. 32 No. 1 pp. 1-21

Beine, M., F. Docquier and H. Rapoport (2008), "Brain Drain and Human Capital Formation in Developing Countries: Winners and Losers”, Economic Journal Vol. 118 pp. 631-652

Co, C.Y., I.N. Gang and Y. Myeong-Su (2000), "Returns to Returning”, Journal of Population Economics Vol. 13 pp. 57-79

De Coulon, A. and M. Piracha (2005), "Self-selection and the Performance of Return Migrants: The Source-county Perspective”, Journal of Population Economics Vol. 18 No. 4 pp. $779-807$

Djajic, S. and R. Milbourne (1988), “A General Equilibrium Model of Guest-worker Migration: A Source-country Perspective”, Journal of International Economics Vol. 25 pp. 335-351

Dustmann, C. (1997a), "Return Migration and the Optimal Migration Duration", Manuscript, University College London

Dustmann, C. (1997b), "Return Migration, Uncertainty and Precautionary Savings", Journal of Development Economics Vol. 52 No. 2 pp. 295-316

Dustmann, C. (2003), “Children and Return Migration”, Journal of Population Economics Vol. 16 pp. 815-830

Dustmann, C. and O. Kirchkamp (2002), “The Optimal Migration Duration and Activity Choice after Re-migration”, Journal of Development Economics Vol. 67 No. 2 pp 351372

Dustmann, C. and Y. Weiss (2007), "Return Migration: Theory and Empirical Evidence from the UK”, British Journal of Industrial Relations Vol. 45 No. 2 pp. 236-256

FitzGerald, J. (2000), “The Story of Ireland's Failure - and Belated Success”, in Nolan, B., P. O’Connell and C.T. Whelan (eds.) Bust to Boom: The Irish Experience of Growth and Inequality, Dublin: Institute of Public Administration

Hazans, M. (2008), "Effect of foreign Experience on Return Migrants' Earnings: Causality and Heterogeneity”, Manuscript, University of Latvia

Jasso, G. and M.R. Rosenzweig (1982), "Estimating the Emigration Rates of Legal Immigrants using Administrative and Survey Data: The 1971 Cohort of Immigrants to the United States”, Demography Vol. 19 pp. 279-290 
Sjaastad, L. A. (1962), “The Costs and Returns of Human Migration”, Journal of Political Economy Vol. 70 pp. 80-93

Warren, R. and J.M. Peck (1980), “Foreign-born Emigration from the United States”, Demography Vol. 17 pp. 71-84 
Table 1: Descriptive Statistics on Stayers and Returners

\begin{tabular}{|c|c|c|c|c|}
\hline & \multicolumn{2}{|c|}{ Stayers } & \multicolumn{2}{|c|}{ Returners } \\
\hline & Mean & Std. Dev. & Mean & Std. Dev. \\
\hline Earnings per week $(€)$ & $719.20 * * *$ & 560.17 & 897.33 & 733.39 \\
\hline Age (years) & $38.98 * * *$ & 12.11 & 41.44 & 10.55 \\
\hline Experience (years) & $18.09 * * *$ & 11.58 & 19.56 & 10.43 \\
\hline Male & $0.51 * * *$ & 0.50 & 0.49 & 0.50 \\
\hline Dublin & 0.28 & 0.45 & 0.29 & 0.45 \\
\hline \multicolumn{5}{|l|}{ Education dummy variables: } \\
\hline Primary & $0.08 * * *$ & 0.26 & 0.04 & 0.19 \\
\hline Secondary & $0.41 * * *$ & 0.49 & 0.24 & 0.43 \\
\hline Post-secondary & 0.27 & 0.45 & 0.27 & 0.44 \\
\hline Degree & $0.16 * * *$ & 0.37 & 0.27 & 0.44 \\
\hline Postgraduate & $0.08 * * *$ & 0.26 & 0.18 & 0.38 \\
\hline Tenure (years) & $10.46^{* * *}$ & 9.61 & 8.46 & 7.70 \\
\hline \multicolumn{5}{|l|}{ Occupation dummy variables: } \\
\hline Managers and senior administrators & $0.11 * * *$ & 0.31 & 0.13 & 0.34 \\
\hline Professionals & $0.19 * * *$ & 0.39 & 0.34 & 0.47 \\
\hline Associate professional and technical & $0.11 * * *$ & 0.31 & 0.12 & 0.33 \\
\hline Clerical and secretarial & $0.20 * * *$ & 0.40 & 0.16 & 0.37 \\
\hline Craft and related trades & $0.07 * * *$ & 0.25 & 0.05 & 0.22 \\
\hline Personal and protective services & $0.08 * * *$ & 0.26 & 0.05 & 0.21 \\
\hline Sales & $0.07 * * *$ & 0.26 & 0.04 & 0.20 \\
\hline Plant and machine operatives & $0.09 * * *$ & 0.28 & 0.05 & 0.23 \\
\hline Other & $0.09 * * *$ & 0.29 & 0.06 & 0.23 \\
\hline \multicolumn{5}{|l|}{ Sector dummy variables ${ }^{9}$ : } \\
\hline Manufacturing, mining & $0.17 * * *$ & 0.37 & 0.13 & 0.34 \\
\hline Electricity, gas, water & 0.01 & 0.08 & 0.01 & 0.09 \\
\hline Construction & 0.07 & 0.25 & 0.07 & 0.26 \\
\hline Wholesale and retail & $0.18 * * *$ & 0.38 & 0.11 & 0.31 \\
\hline Hotels and restaurants & $0.04 * *$ & 0.19 & 0.03 & 0.18 \\
\hline Transport, storage, communication & $0.05 * * *$ & 0.22 & 0.04 & 0.19 \\
\hline Financial intermediation & 0.07 & 0.25 & 0.07 & 0.25 \\
\hline Business services & $0.12 * * *$ & 0.32 & 0.15 & 0.35 \\
\hline Public admin and defence & $0.10 * * *$ & 0.30 & 0.08 & 0.28 \\
\hline Education & $0.06 * * *$ & 0.24 & 0.08 & 0.28 \\
\hline Health and social work & $0.11 * * *$ & 0.31 & 0.19 & 0.39 \\
\hline \multirow[t]{2}{*}{ Other } & $0.05 * * *$ & 0.21 & 0.04 & 0.19 \\
\hline & \multicolumn{2}{|c|}{$\mathrm{N}=36,627$} & \multicolumn{2}{|c|}{$\mathrm{N}=6,216$} \\
\hline
\end{tabular}

\footnotetext{
${ }^{9}$ Electricity, gas, water is included as a sector in the data but the number of returners is too small for the percentage to be meaningful.
} 
$* * \mathrm{P}<0.05 * * * \mathrm{P}<0.01$

Table 2: OLS Wage Regressions

\begin{tabular}{lll}
\hline Dependent Variable: Weekly Earnings & & \\
\hline & & \\
Returner & $0.07^{* * *}$ & $(0.01)$ \\
Male & $0.33^{* * *}$ & $(0.01)$ \\
Dublin & $0.16^{* * *}$ & $(0.01)$ \\
Age & $0.08^{* * *}$ & $(0.00)$ \\
Age & $0.00^{* * *}$ & $(0.00)$ \\
Experience & $0.01^{* * *}$ & $(0.00)$ \\
Experience & & $(0.00)$ \\
Education & 0.00 & \\
$\quad$ Primary (omitted) & & \\
$\quad$ Secondary & & \\
$\quad$ Post-secondary & $0.10^{* * *}$ & $(0.01)$ \\
$\quad$ Degree & $0.25^{* * *}$ & $(0.01)$ \\
$\quad$ Postgraduate & $0.46^{* * *}$ & $(0.01)$ \\
Tenure & $0.51^{* * *}$ & $(0.02)$ \\
Constant & $0.01^{* * *}$ & $(0.00)$ \\
& $4.25^{* * *}$ & $(0.04)$ \\
Adjusted R & & \\
& &
\end{tabular}

Occupation and sector controls were also included.

Standard errors in parentheses.

$* * * \mathrm{P}<0.01$

Table 3: Propensity Score Estimates of the Returned Migrant Wage Premium

\begin{tabular}{lcccc}
\hline & \multicolumn{3}{c}{ Nearest Neighbour } & \multicolumn{2}{c}{ Kernel } \\
\hline Returner & 0.01 & $(0.02)$ & $0.08^{* * *}$ & $(0.01)$ \\
& & & & \\
\hline $\begin{array}{l}\text { Standard errors in parentheses. } \\
* * * \mathrm{P}<0.01\end{array}$ & & & & \\
\hline
\end{tabular}


Table 4: PSM Sensitivity Check: Rosenbaum Bounds

\begin{tabular}{lll}
\hline Gamma & Sig + & Sig - \\
\hline & & \\
1 & 0.00 & 0.00 \\
1.1 & 0.00 & 0.00 \\
1.2 & 0.00 & 0.00 \\
1.3 & 0.00 & 0.00 \\
1.4 & 0.00 & 0.00 \\
1.5 & 0.00 & 0.00 \\
1.6 & 0.09 & 0.00 \\
1.7 & 0.76 & 0.00 \\
1.8 & 0.99 & 0.00
\end{tabular}

Gamma: Log odds of differential assignment due to unobserved factors

Sig +: Upper bound p-value

Sig -: Lower bound p-value

Table 5: Returned Migrant Wage Premium by Gender

\begin{tabular}{lccc}
\hline & $\mathbf{N}$ & \multicolumn{2}{c}{ Coefficient on Returner Dummy } \\
\hline Men & & & \\
Women & 21,624 & $0.07^{* * *}$ & $(0.01)$ \\
& 21,219 & $0.07^{* * *}$ & $(0.01)$ \\
\hline
\end{tabular}

Standard errors in parentheses.

$* * * \mathrm{P}<0.01$

Table 6: Returned Migrant Wage Premium by Educational Attainment

\begin{tabular}{llll}
\hline & $\mathbf{N}$ & Coefficient on Returner Dummy \\
\hline & & & \\
Postgrad & 3,887 & $0.10^{* * *}$ & $(0.02)$ \\
Degree & 7,628 & $0.06^{* * *}$ & $(0.02)$ \\
Post secondary & 11,703 & $0.05^{* * *}$ & $(0.01)$ \\
Secondary & 16,631 & $0.05^{* * *}$ & $(0.02)$ \\
Primary & 2,994 & $0.13^{* * *}$ & $(0.04)$
\end{tabular}


Standard errors in parentheses.

$* * * \mathrm{P}<0.01$

Table 7: Returned Migrant Earnings and Number of Years Since Return

Years Since Return $\quad-0.01^{* * *} \quad(0.00)$

Dependent Variable: Returned migrant earnings

Standard errors in parentheses.

$* * * \mathrm{P}<0.01$

Table 8: Returned Migrant Wage Premium (returners who worked while abroad vs those who did not)

$0.06 * * *$

Returners who did not work

$0.03 * *$

$(0.01)$

$(0.01)$

Standard errors in parentheses.

$* * \mathrm{P}<0.05 * * * \mathrm{P}<0.01$

Table 9: Returned Migrant Wage Premium by Migration Destination

Coefficient on Returner Dummy

$\begin{array}{lll}\text { UK } & 0.05^{* * *} & (0.01) \\ \text { US/Canada } & 0.11^{* * *} & (0.02) \\ \text { EU } & 0.04 & (0.03) \\ \text { Australia/New Zealand } & 0.10^{* * *} & (0.02) \\ \text { Other } & 0.11^{* * *} & (0.03)\end{array}$


Standard errors in parentheses.

$* \mathrm{P}<0.10 * * \mathrm{P}<0.05 * * * \mathrm{P}<0.01$ 